\title{
Management of severely brittle diabetes by continuous subcutaneous and intramuscular insulin infusions: evidence for a defect in subcutaneous insulin absorption
}

\author{
J C PICKUP, P D HOME, R W BILOUS, H KEEN, K G M M ALBERTI
}

\begin{abstract}
Severely brittle diabetes is defined as a rare subtype of insulin-dependent diabetes with wide, fast, unpredictable, and inexplicable swings in blood glucose concentration, often culminating in ketoacidosis or hypoglycaemic coma. To assess the role of inappropriate type, amount, or timing of insulin treatment and the route of administration as a cause of severe brittleness six patients with brittle diabetes were studied during variable-rate, continuous subcutaneous insulin infusion, which provides a high degree of optimisation of dosage with exogenous insulin in stable diabetics. The glycaemic control achieved during continuous subcutaneous insulin infusion was compared with that during continuous intramuscular insulin infusion. Six patients with non-brittle diabetes were also treated by continuous subcutaneous insulin infusion. These patients achieved the expected improvement in glycaemic control (mean $\perp$ SD plasma glucose concentration $5 \cdot 12 \cdot 3 \mathrm{mmol} / 1(92 \pm 41 \mathrm{mg} / 100 \mathrm{ml}))$, but the patients with brittle diabetes remained uncontrolled with continuous subcutaneous infusion $(13.6+5.8 \mathrm{mmol} / 1$ $(245-105 \mathrm{mg} / 100 \mathrm{ml})$ compared with $10 \cdot 3 \mathrm{mmol} / 1$ $(18674 \mathrm{mg} / 100 \mathrm{ml})$ during treatment with optimised conventional subcutaneous injections). During continuous intramuscular infusion, however, glycaemic control in five of the patients with brittle diabetes was significantly improved $(7 \cdot 7+2.6 \mathrm{mmol} / 1(139+47 \mathrm{mg} / 100$ $\mathrm{ml})$ ). The remaining patient with brittle diabetes,
\end{abstract}

\footnotetext{
Unit for Metabolic Medicine, Guy's Hospital Medical School, London SE1 9RT

J C PICKUP, DPHIL, honorary lecturer

$\mathrm{R}$ W BILOUS, MRCP, research registrar

H KEEN, FRCP, professor

Department of Clinical Biochemistry and Metabolic Medicine, Royal Victoria Infirmary, Newcastle upon Tyne NE1 4LP

P D HOME, MRCP, research fellow

K G M M ALBERTI, FRCP, professor
}

previously safely controlled only with continuous intravenous insulin, did not respond to continuous intramuscular infusion.

It is concluded that in five of the six patients with brittle diabetes studied here impaired or irregular absorption of insulin from the subcutaneous site played a more important part in their hyperlability than inappropriate injection strategies. This absorption defect was presumably bypassed by the intramuscular route.

\section{Introduction}

A small proportion of insulin-dependent diabetics exhibit a severe metabolic derangement characterised by wide, fast, unpredictable, and inexplicable swings in blood glucose concentration, sometimes culminating in ketoacidosis or symptomatic hypoglycaemia. These wide oscillations occur despite constancy of insulin injections, exercise and diet and in the face of the most strenuous corrective efforts of both doctor and patient. ${ }^{1}$ Many of these patients with extremely brittle diabetes are frequently admitted to hospital as emergencies with ketoacidosis or hypoglycaemia. In such patients diabetes threatens, at best, the lifestyle and, at worst, life itself. ${ }^{2}$

The mechanisms responsible for severely brittle diabetes are poorly understood. One possible cause is clinical mismanagement, leading to inappropriate insulin action, in respect of the type of insulin (for example, duration of action), the quantity (for example, dosage based on results of urine tests in diabetics with a low renal threshold for glucose), or timing of the injection in relation to food intake. The theory of mismanagement has been difficult to test because of disagreement about which regimen constitutes optimal conventional management. The technique of continuous subcutaneous insulin infusion, ${ }^{34}$ however, using a portable, variable-rate syringe pump, enables prolonged near-normoglycaemia to be achieved in stable insulindependent diabetics ${ }^{5-12}$ and thus represents an objective standard against which the results of other regimens may be compared. Adjustment of both the basal insulin delivery rate and the timing and magnitude of the mealtime insulin boost for 
each diabetic, achievable with continuous subcutaneous infusion, provides a high degree of optimisation of dosage with exogenous insulin.

We report here a comparison of the blood glucose control in six patients with brittle diabetes during optimised treatment with conventional subcutaneous injection and during several days of continuous subcutaneous infusion. A control group of patients with non-brittle insulin-dependent diabetes were also studied during conventional injections and continuous subcutaneous insulin infusion. The role of the route of administration of insulin in brittle diabetes was further explored by comparing glycaemic control during continuous subcutaneous insulin infusion with that during continuous intramuscular insulin infusion.

\section{Patients and methods}

\section{PATIENTS}

The experimental aspects of the studies were clearly explained to the patients, who gave their consent to participation. All procedures had been submitted to and approved by the hospital ethical committees concerned.

Table I summarises the main clinical features of the patients with severely brittle diabetes and the controls. Five of the six patients with
The control patients were volunteers selected from the diabetic clinic and not thought on clinical grounds to have brittle diabetes (table I).

\section{PROCEDURES}

Patients were admitted to a metabolic ward for all studies. Initially plasma glucose profiles were obtained during the prevailing conventional injection treatment. Venous or capillary blood was withdrawn at least two hourly during the day and night from an indwelling Teflon cannula or earlobe puncture for one to three days.

Continuous subcutaneous insulin infusion was given for five to 11 days according to the techniques previously described ${ }^{3} 57$ except that the infusion pump used was the model 1001HM Mill Hill Infuser (Muirhead Medical Ltd, London SE25). This pump incorporates a calibrated manual advance of the lead screw so that a measurable and variable insulin boost may be deposited at the cannula tip before meals (in multiples of $53 \mu \mathrm{l}$ ). The basal infusion rate was $66 \mu \mathrm{l} / \mathrm{h}$. Highly purified porcine insulin (Actrapid, Novo Ltd) was diluted from 200 or $80 \mathrm{U} / \mathrm{ml}$ stock insulin solution with $0.154 \mathrm{~mol} / \mathrm{l}$ sterile saline $(900 \mathrm{mg} / 100 \mathrm{ml}$ ) according to individual needs. The pump syringe was refilled and replaced daily. The insulin boost was activated by the patient 30 minutes before breakfast, lunch, and the evening meal. Table II shows the proportions of insulin administered to the patients with brittle diabetes at the basal and preprandial rates. The infusion cannula was either a fine nylon cannula (Portex Ltd, Hythe,

TABLE I-Clinical features of patients

\begin{tabular}{|c|c|c|c|c|c|c|c|c|c|}
\hline \multirow{2}{*}{$\begin{array}{l}\text { Case } \\
\text { No }\end{array}$} & \multirow[t]{2}{*}{ Sex } & \multirow{2}{*}{$\underset{(\text { years })}{\text { Age }}$} & \multirow{2}{*}{$\begin{array}{l}\text { Known } \\
\text { duration of } \\
\text { diabetes } \\
\text { (years) }\end{array}$} & \multirow{2}{*}{$\begin{array}{c}\text { No of } \\
\text { acute } \\
\text { admissions } \\
\text { to hospital }\end{array}$} & \multicolumn{4}{|c|}{$\begin{array}{c}\text { Conventional insulin dose } \\
(\mathrm{U} / \mathrm{day})^{*}\end{array}$} & \multirow{2}{*}{$\begin{array}{c}\text { Duration of } \\
\text { instability } \\
\text { (years) }\end{array}$} \\
\hline & & & & & am & & $\overline{\mathrm{pm}}$ & & \\
\hline \multicolumn{10}{|c|}{ Patients with brittle diabetes } \\
\hline 1 & $\mathrm{~F}$ & 27 & 18 & 50 & \multirow{2}{*}{\multicolumn{2}{|c|}{$\begin{array}{lr}\text { AR } & 44 \\
\text { RT } & 60 \\
\text { RT } & 36 \\
\text { LN } & 16 \\
\text { LN } & 8\end{array}$}} & \multirow{2}{*}{$\begin{array}{l}\mathrm{AR} \\
\mathrm{RT} \\
\mathrm{RT} \\
\mathrm{LN}\end{array}$} & \multirow{2}{*}{$\begin{array}{l}50 \\
70 \\
16 \\
12\end{array}$} & 9 \\
\hline 2 & $\mathrm{~F}$ & 28 & 24 & 7 & & & & & 3 \\
\hline 3 & $\mathrm{~F}$ & 20 & 5 & 43 & \multirow{3}{*}{\multicolumn{2}{|c|}{\begin{tabular}{lr}
\multicolumn{2}{c}{ (noon) } \\
AR & 12 \\
$\mathrm{MT}$ & 10 \\
$\mathrm{AR}$ & 28 \\
$\mathrm{RT}$ & 12 \\
$\mathrm{AR}$ & 6 \\
$\mathrm{UT}$ & 28 \\
$\mathrm{AR}$ & 6
\end{tabular}}} & \multirow{4}{*}{$\begin{array}{l}\mathrm{AR} \\
\mathrm{MT} \\
\mathrm{AR} \\
\mathrm{RT} \\
\mathrm{AR}\end{array}$} & \multirow{4}{*}{$\begin{array}{r}2 \\
8 \\
20 \\
20 \\
10\end{array}$} & \\
\hline 4 & $\mathrm{~F}$ & 13 & 5 & 50 & & & & & $2 \cdot 5$ \\
\hline 5 & $\mathrm{~F}$ & 35 & 25 & 0 & & & & & $\begin{array}{l}1 \cdot 5 \\
9\end{array}$ \\
\hline 6 & $\mathrm{~F}$ & 20 & 13 & 28 & $\mathrm{AR}^{\text {(noor }}$ & n) & & & 5 \\
\hline \multicolumn{10}{|c|}{ Patients with non-brittle diabetes } \\
\hline $\begin{array}{l}7 \\
8 \\
9\end{array}$ & $\begin{array}{l}M \\
M \\
M\end{array}$ & $\begin{array}{l}21 \\
49 \\
52\end{array}$ & $\begin{array}{r}11 \\
24 \\
6\end{array}$ & $\begin{array}{l}0 \\
2 \\
0\end{array}$ & \multirow{4}{*}{$\begin{array}{l}\text { S } \\
\text { RT } \\
\text { S } \\
\text { NPH } \\
\text { S } \\
\text { NPH } \\
\text { PZI } \\
\text { S } \\
\text { PZI } \\
\text { S }\end{array}$} & $\begin{array}{l}32 \\
44 \\
24\end{array}$ & \multirow{4}{*}{$\begin{array}{l}\text { S } \\
\text { RT } \\
\text { S } \\
\text { NPH } \\
\text { S } \\
\text { NPH }\end{array}$} & \multirow{4}{*}{$\begin{array}{r}40 \\
28 \\
28 \\
8 \\
8 \\
4\end{array}$} & \\
\hline 10 & $\mathrm{~F}$ & 32 & 26 & 2 & & $\begin{array}{l}8 \\
6 \\
8\end{array}$ & & & \\
\hline 11 & $\mathrm{~F}$ & 16 & 10 & 2 & & 32 & & & \\
\hline 12 & $\mathrm{~F}$ & 20 & 15 & 1 & & $\begin{array}{l}24 \\
26 \\
32\end{array}$ & & & \\
\hline
\end{tabular}

*AR = Actrapid $; \mathrm{RT}=$ Rapitard $; \mathrm{LN}=$ Leo Neutral; $\mathrm{MT}=$ Monotard $; \mathrm{UT}=$ Ultratard; S = Soluble; NPH = Isophane; PZI =

†rotamine zinc insulin.

brittle diabetes had been referred to these hospitals by doctors at other centres (because of difficulties with control). Strenuous but unsuccessful attempts had been made to achieve good control during conventional insulin injection treatment including using long-term glycaemic self-monitoring and frequent dosage adjustments. The representative injection regimens shown in table I are those applicable when the patients were admitted to the study. One patient (case 6) could not be safely managed by subcutaneous injections and had received continuous intravenous insulin infusion in hospital during the previous six months.

Five patients (cases 1-4,6) had been admitted to hospital many times with ketoacidosis or hypoglycaemia. One patient (case 5) had had no acute emergency hospital admissions but had suffered for at least nine years wide and unpredictable swings of blood glucose concentration associated with multiple episodes of symptomatic hypoglycaemia. Diabetes was associated with a major upset of life style in all six patients with brittle diabetes. All were emotionally distressed, with difficult social or domestic backgrounds not obviously caused by their diabetes though often aggravated by it.
Kent), the distal $3 \mathrm{~cm}$ of which was implanted subcutaneously in the anterior abdominal wall, ${ }^{3}$ or a 25 -gauge "Butterfly" needle (Abbott Ltd, Queenborough, Kent). The nylon cannula remained implanted at a single site for the entire study but the Butterfly needle was changed daily by the patient.

Continuous intramuscular insulin infusion (using the same syringe pump as for continuous subcutaneous infusion) was usually into the deltoid muscle, except during the first nine weeks in one patient (case 2 ), when the rectus abdominis was used. For deltoid insertion the skin overlying the deltoid muscle was cleaned with antiseptic solution and the skin and subcutaneous tissue anaesthetised with $1 \%$ lignocaine solution. A 16-gauge Medicut needle (Sherwood Medical Industries) was inserted into the muscle through the anaesthetised skin and the inner metal needle withdrawn, leaving the plastic sheath in situ. A fine nylon cannula, filled to the tip with the appropriate insulin solution (as used for continuous subcutaneous infusion), was fed into the muscle, through the plastic sheath, using sterile forceps. The plastic sheath was withdrawn over the nylon cannula and taken back to the hub of the cannula. The cannula was fixed to the skin overlying

.


the deltoid by securing several loops with waterproof plaster. For insertion into the rectus abdominis muscle $1 \%$ lignocaine solution was infiltrated subcutaneously in the paraumbilical region. The rectus sheath was exposed surgically and the insulin-filled cannula sutured into the rectus muscle. The incision was closed with subcuticular stitches. The preprandial insulin boost was activated 15 minutes before main meals. The proportions at basal and augmented rates are shown in table II.

TABLE II-Insulin dose (units/day) during continuous subcutaneous and intramuscular infusions in five patients with brittle diabetes

\begin{tabular}{|c|c|c|c|c|c|c|}
\hline \multirow{2}{*}{$\begin{array}{l}\text { Case } \\
\text { No }\end{array}$} & \multicolumn{3}{|c|}{ Continuous subcutaneous infusion } & \multicolumn{3}{|c|}{ Continuous intramuscular infusion } \\
\hline & Basal & Preprandial & Total & Basal & Preprandial & Total \\
\hline $\begin{array}{l}1 \\
2 \\
3 \\
4 \\
5\end{array}$ & $\begin{array}{r}36 \\
183 \\
22 \\
76 \\
29\end{array}$ & $\begin{array}{r}22 \\
110 \\
9 \\
38 \\
6\end{array}$ & $\begin{array}{r}58 \\
293 \\
31 \\
114 \\
35\end{array}$ & $\begin{array}{l}25 \\
63 \\
19 \\
76 \\
40\end{array}$ & $\begin{array}{r}15 \\
38 \\
8 \\
38 \\
9\end{array}$ & $\begin{array}{r}40 \\
101 \\
27 \\
114 \\
49\end{array}$ \\
\hline
\end{tabular}

Analysis-Plasma glucose concentration was measured by a glucose oxidase method using an automatic glucose analyser (Analox Instruments, London SW13). Concentrations during the various regimens were compared by the Wilcoxon rank sum test for distribution-free data or Student's $t$ test, as appropriate.

\section{Results}

The figure shows the plasma glucose control throughout the day in five of the patients with severely brittle diabetes (cases 1-5) during the various treatment regimens. Control during their prevailing

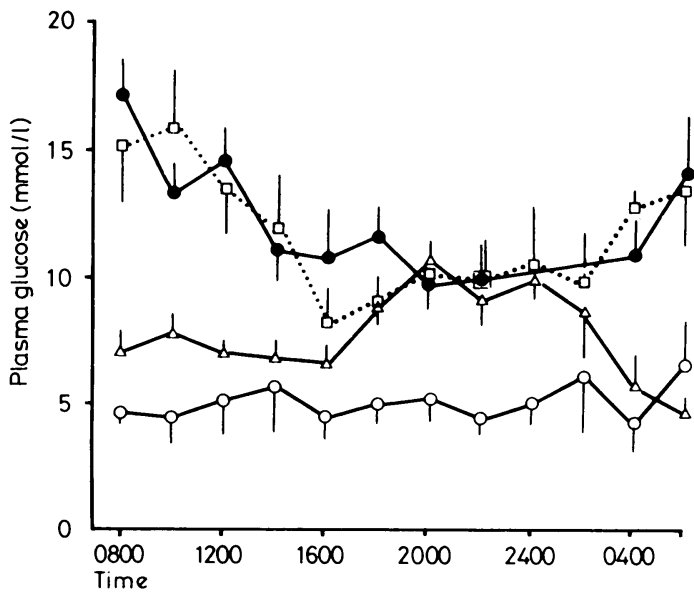

Mean + SEM plasma glucose concentrations over 24 hours in six patients with non-brittle insulin-dependent diabetes during continuous subcutaneous insulin infusion $(\mathrm{O}-\mathrm{O})$ and in five patients with brittle diabetes during continuous subcutaneous insulin infusion ( -0 ), continuous intramuscular insulin infusion $(\triangle-\triangle)$, and optimised conventional subcutaneous injections $(\square \cdots \square)$.

Conversion: SI to traditional units-Plasma glucose: $\mathrm{mmol} / 1 \approx 18 \mathrm{mg} / 100 \mathrm{ml}$.

optimised conventional subcutaneous injections was similar to that during continuous subcutaneous infusion and unsatisfactory with both treatments. Control in these patients during continuous intramuscular infusion, however, was significantly improved at several times $(p<0.001$ at $0800,1000,1200,1400$, and $0600 ; p<0.05$ at 0400 ; continuous intramuscular $v$ subcutaneous infusion). By contrast, the six control patients with non-brittle diabetes were well controlled during continuous subcutaneous infusion (figure). The overall mean $( \pm \mathrm{SD})$ daily plasma glucose concentration was $5 \cdot 1 \pm 2.3 \mathrm{mmol} / \mathrm{l}$ $(92+41 \mathrm{mg} / 100 \mathrm{ml})$.

Table III shows the individual mean plasma glucose concentrations during continuous subcutaneous and intramuscular infusions in the patients with brittle diabetes. Both the mean concentrations and the oscillations in concentration (as shown by the standard deviation) were reduced during continuous intramuscular infusion compared with continuous subcutaneous infusion, although the total daily insulin dose given with the two regimens was usually similar (table II). In one patient (case 2) the intramuscular dose was $35 \%$ of the subcutaneous infusion dose (table II); notwithstanding this, the glycaemic control was significantly improved during intramuscular administration $(\mathrm{p}<0.001)$.

TABLE III-Mean $( \pm S D)$ plasma glucose control (mmolll) during continuous subcutaneous and intramuscular insulin infusions in five patients with severely brittle diabetes

\begin{tabular}{|c|c|c|c|c|}
\hline \multirow{2}{*}{$\begin{array}{c}\text { Case } \\
\text { No }\end{array}$} & \multicolumn{2}{|c|}{$\begin{array}{l}\text { Continuous } \\
\text { subcutaneous infusion }\end{array}$} & \multicolumn{2}{|c|}{$\begin{array}{l}\text { Continuous } \\
\text { intramuscular infusion }\end{array}$} \\
\hline & $\begin{array}{l}13 \cdot 1 \pm 7.3 \\
12 \cdot 3 \pm 5 \cdot 0 \\
10.5 \pm 4.5 \\
17.5 \pm 5.9 \\
12.8 \pm 6.5\end{array}$ & $\begin{array}{l}(n=34) \\
(n=93) \\
(n=19) \\
(n=19) \\
(n=87)\end{array}$ & $\begin{array}{r}6 \cdot 8 \pm 3.4 \\
7.8 \pm 3 \cdot 0 \\
6.0 \pm 0.9 \\
7 \cdot 3 \pm 2.5 \\
10.7 \pm 3.4\end{array}$ & $\begin{array}{l}(n=54) \\
(n=65) \\
(n=19) \\
(n=18) \\
(n=35)\end{array}$ \\
\hline Mean & $13 \cdot 6 \pm 5 \cdot 8^{*}$ & & $7 \cdot 7 \pm 2 \cdot 6^{*}$ & \\
\hline
\end{tabular}

In case 6 continuous subcutaneous infusion and intramuscular infusion were attempted but within a few hours intravenous insulin was necessary to maintain control. For example, during continuous intramuscular infusion at a basal rate of $317 \mathrm{U} /$ day and with a single preprandial boost (given at time $0.5 \mathrm{~h}, 15$ minutes before a meal) of 53 U plasma glucose concentration rose from $3.1 \mathrm{mmol} / 1(54 \mathrm{mg} / 100 \mathrm{ml})$ at time 0 to $29 \cdot 1 \mathrm{mmol} / 1(524 \mathrm{mg} / 100 \mathrm{ml})$ at four hours. The infusion pump was functioning normally and the intramuscular cannula was correctly implanted.

\section{Discussion}

In most insulin-dependent diabetics continuous subcutaneous insulin infusion using a variable-rate portable pump produces near-normalisation of blood concentrations of glucose and major intermediary metabolites, ${ }^{3-12}$ usually with an insulin dose equivalent to or less than that given with the prevailing conventional treatment. ${ }^{8}$ The freedom to adjust the basal insulin delivery rate and the timing and magnitude of the mealtime boosts (independently of each other) ordinarily gives nearnormal profiles of glycaemia and allowed us to test the possibility that inappropriate insulin dosage was a cause of the extreme brittleness in these patients. The stable insulin-dependent diabetics in this study responded well to continuous subcutaneous infusion, but the patients with brittle diabetes were not improved, suffering wide swings in plasma glucose concentrations. Attempts to increase the insulin dose given by continuous subcutaneous infusion resulted in more frequent hypoglycaemic episodes.

By contrast, up to nine days' treatment with continuous intramuscular infusion under hospital conditions appreciably improved plasma glucose concentrations in all but one of the patients with brittle diabetes, although complete normalisation of glycaemia (particularly from 1800 to 0200 ) was not obtained. We have no ready explanation for the behaviour in the unresponsive patient and suppose that a different type of or more severe lability may have been the cause.

In most patients improved control by continuous intramuscular infusion occurred at a similar or lower total daily insulin dose compared with continuous subcutaneous infusion. This suggests improved access of insulin to the circulation during intramuscular infusion and that a major factor in the hyperlability of the patients studied was impaired or irregular absorption of insulin from the subcutaneous site, or both, rather than inappropriate subcutaneous treatment. The absorption barrier was presumably bypassed by the intramuscular route. 
This interpretation is supported by preliminary results showing predictable plasma free insulin concentrations in patients with brittle diabetes during continuous intramuscular infusion but erratic free insulin profiles during continuous subcutaneous infusion..$^{13}$

Factors such as the variation in local subcutaneous blood flow and enzymatic destruction of insulin under the skin may contribute to the metabolic derangement but have not been studied in detail in this type of diabetic subgroup.

Interestingly, several insulin-dependent diabetics have been described with considerable resistance to subcutaneously injected insulin but a satisfactory response to intravenous administration,,$^{14-19}$ and there is increasing evidence for subcutaneous degradation of injected insulin in diabetics. ${ }^{20}$ The protease inhibitor aprotinin appears to increase the rate and absolute amount of insulin absorbed from the subcutaneous tissue of non-diabetics ${ }^{21}$ and reduces the subcutaneous insulin requirements in some insulin-resistant diabetics. ${ }^{1819}$ We recently described a diabetic with massive resistance to subcutaneous insulin injections and continuous subcutaneous insulin infusion who was significantly better controlled by continuous intramuscular infusion. ${ }^{22} 23$ In this patient aprotinin was ineffective. One patient in this study (case 1) required more than $200 \mathrm{U}$ insulin/day, and possibly there may be aetiological overlap and several common clinical features among patients with severely brittle diabetes and some insulin-resistant diabetics.

We treated two of the patients reported on here by long-term continuous intramuscular infusion at home, one for one year (unpublished). We would not yet recommend this as a therapeutic method for brittle diabetes, however, except under exceptional circumstances. Difficulties such as the insertion and long-term securing of the intramuscular cannula and the intensive outpatient supervision required render continuous intramuscular insulin infusion a short-term research tool.

We thank the staff of the metabolic ward at Guy's Hospital and Ward 15, Freeman Hospital, Newcastle, for their help and the patients for their enthusiastic co-operation. Dr R B Tattersall, Dr J D Ward, Dr J Lister, and Dr E Barnes kindly allowed us to study their patients. Dr E M Kohner and Dr M C White helped with the infusion studies in non-brittle diabetics. Novo Ltd, Basingstoke, generously supplied special $200 \mathrm{U}$ insulin $/ \mathrm{ml}$.

JCP was supported by the British Insulin Manufacturers and the Medical Research Council. PDH was a Novo research fellow. The support of the Minet Trust in the supply of calculating and graphic facilities is gratefully acknowledged. The British Diabetic Association supplied additional financial support.

\section{References}

${ }^{1}$ Molnar GD. Observations on the etiology and therapy of "brittle" diabetes. Can Med Assoc 7 1964;90:953-9.

2 Tattersall RB. Brittle diabetes. Clin Endocrinol Metab 1977;6:403-19.

${ }^{3}$ Pickup JC, Keen H, Parsons JA, Alberti KGMM. Continuous subcutaneous insulin infusion: an approach to achieving normoglycaemia. Br Med f 1978;i:204-7.

4 Pickup JC, Keen H. Continuous subcutaneous insulin infusion: a developing tool in diabetes research. Diabetologia 1980;18:1-4.

5 Pickup JC, Keen H, Parsons JA, Alberti KGMM. Continuous subcutaneous insulin infusion: good blood glucose control for up to 4 days. Diabetologia 1979;16:385-9.

${ }^{6}$ Pickup JC, Keen H, Parsons JA, Alberti KGMM, Rowe AS. Continuous subcutaneous insulin infusion: improved blood glucose and intermediary metabolite control in diabetics. Lancet 1979 ; : 1255-8.

7 Pickup JC, White MC, Keen H, Kohner EM, Parsons JA, Alberti KGMM. Long-term continuous subcutaneous insulin infusion in diabetics at home. Lancet $1979 ; \mathrm{ii}: 870-3$.

${ }^{8}$ Pickup JC, Keen H, Viberti GC, et al. Continuous subcutaneous insulin infusion in the treatment of diabetes mellitus. Diabetes Care 1980;3: 290-300.

9 Tamborlane WV, Sherwin RS, Genel M, Felig P. Reduction to normal of plasma glucose in juvenile diabetes by subcutaneous administration of insulin with a portable infusion pump. $N$ Engl f Med 1979;300:573-8.

10 Tamborlane WV, Sherwin RS, Genel M, Felig P. Restoration of normal lipid and amino acid metabolism in diabetic patients with a portable insulin infusion pump. Lancet 1979;i:1258-61.
11 Tamborlane WV, Sherwin RS, Genel M, Felig P. Outpatient treatment of juvenile-onset diabetes with a preprogrammed portable subcutaneous insulin infusion system. Am F Med 1980;68:190-6.

12 Champion MC, Shepherd GAA, Rodger NW, Dupré J. Continuous subcutaneous insulin infusion in the management of diabetes mellitus. Diabetes $1980 ; 29: 206-12$.

${ }^{13}$ Home PD, Massi-Benedetti M, Shepherd GAA, Alberti KGMM. 24-hour plasma free insulin profiles in brittle diabctics treated by continuous intramuscular and subcutaneous insulin infusion. Diabetologia $1980 ; 19$ : 284.

${ }^{14}$ Schneider AG, Bennett RH. Impaired absorption of insulin as a cause of insulin resistance. Diabetes $1975 ; \mathbf{2 4}$, suppl 1:443.

${ }^{15}$ Dandona P, Healey F, Foster M, Greenbury E, Beckett AG. Low-dose insulin infusions in diabetic patients with high insulin requirements. Lancet 1978; ii:283-5.

${ }^{16}$ Henry DA, Lowe JM, Citrin D, Manderson WG. Defective absorption of injected insulin. Lancet 1978;ii:741.

17 Paulsen EP, Courtney JW, Duckworth WC. Insulin resistance caused by massive degradation of subcutaneous insulin. Diabetes $1979 ; 28: 640-5$.

${ }^{18}$ McElduff A, Eastman CJ, Haynes SP, Bowen KM. Apparent insulin resistance due to abnormal enzymatic insulin degradation: a new mechanism for insulin resistance. Aust NZ F Med 1980;10:56-61.

19 Freidenberg G, White N, Cataland S, O'Dorisio T, Sotos J, Santiago J. Effectiveness of aprotinin (Trasylol) in protease-mediated insulin resistance. Diabetes $1980 ; 29: 23 \mathrm{~A}$

${ }^{20}$ Berger M, Halban PA, Girardier L, Seydoux J, Offord RE, Renold AE. Absorption kinetics of subcutaneously injected insulin: evidence for degradation at the injection site. Diabetologia $1979 ; 17: 97-9$.

${ }^{21}$ Berger M, Cuppers HJ, Halban P, Offord RE. The effect of aprotinin on the absorption of subcutaneously injected regular insulin in norma subjects. Diabetes $1980 ; 29: 81-3$.

${ }^{22}$ Pickup JC, Bilous RW, Keen H. Aprotinin and insulin resistance. Lancet 1980;ii:93-4.

${ }^{23}$ Bilous RW, Pickup JC, Keen H. Massive resistance to subcutaneous insulin administration in a diabetic patient. Diabetologia (in press).

(Accepted 2 December 1980)

ONE HUNDRED YEARS AGO Sir,-Many will agree with the gentleman who says in your last week's issue that the failure of so many young men, at the College of Surgeons, is caused by the miserably imperfect manner in which students of the present day are educated in our metropolitan medical schools. In the first place, many of our hospitals are overstocked with students, who cannot possibly have the attention and facilities due to them which they require during their anatomical and surgical education. In many hospitals, students are allowed to be surgeon's dressers before they have passed their primary examination, which, I think most will agree with me, ought not to be allowed, especially in a hospital with a limited number of beds, as it debars most students who have passed their anatomical examination from dressing ; and most men prefer waiting for a dressership at their own hospital to going elsewhere. Again, the regulations, I believe, at all hospitals, require all first and second year's students to attend the hospital surgical wards daily; also the post mortem and out-patient rooms. Now, in justice to the more advanced students who are reading for their final examination, would it not be a grand addition to our hospital regulations if the first and second year's students were debarred from these several departments until they have passed their primary examination, thereby giving more room for the advanced ones to examine patients for themselves, and also better opportunity for the surgeon present to interrogate his men who are preparing for their examination ? Having been in a large hospital myself, I can positively say that overcrowding of the out-patient rooms by first and second year's students is a great drawback to the senior men, who cannot frequently have a glance at the patient, much less examine him for themselves. This is the feeling amongst senior men in large hospitals, which can be confirmed by not a few. In most schools, the demonstrators of anatomy are supposed to take the men preparing for examination twice or thrice a week; but now the system of "cramming" seems to be so prevalent in every hospital, that, unless a student has a private coach, the chances are he will not even pass the test examination for the first lot in April, although he might be very well prepared for it, as the demonstrators send in their picked men at that time. Many men would be glad to see demonstrators of anatomy not allowed to take private pupils during hospital hours, as they cannot possibly have the same energy and patience with a public class immediately after cramming a private one. I hope some of the leading surgeons will take this subject in hand.-I am, yours truly, Thomas HugH Jones. (British Medical fournal, 1881.) 